Vol. 2, No. 2, 2021

Oleg Mironyuk

Lviv National Agrarian University

1, V. Velykoho Str., Dubliany, 80381, Ukraine

(C) O. Mironyuk, 2021

https://doi.org/10.23939/tt2021.02.052

\title{
ASSESSMENT OF THE NOISE LEVEL ON ARTERIAL STREETS DEPENDING ON TRAFFIC FLOW INDICATORS
}

\begin{abstract}
Summary. The intensity of traffic flows increases every year and intensifies its impact significantly on urban territory's ecologic situation and natural environment. In Ukrainian cities, the growth of noise pollution is quite a topical problem as it has a significant impact on the environment because of the increase in car numbers. Traffic flow intensity and densification of the built-up area cause the increase of the noise level. As analytical methods of calculation of determination of traffic noise level have several disadvantages, then for assessing the level of noise on arterial streets of Lviv city, research is carried out with consideration of traffic flow indicators. One of the critical criteria that have an impact on noise pollution in the urban environment is traffic flow composition. Conducted research indicates that the speed of traffic flow creates significant noise pollution, especially on those streets where cobblestone is a road pavement. Freight and passenger transport that moves along arterial streets causes the increase of noise level and increases its impact on the city territory. On sections of arterial streets in peak periods of the day with high values of volumecapacity ratio and general share of freight and public transport of more than $30 \%$ in a flow, the noise exceeds the acceptable norms and has a harmful impact on the environment. That is why it is necessary to assess noise pollution and the development of protection measures from noise during the planning and construction of some urban regions or residential areas. It is established that to lower the noise level on streets, it is necessary to consider existing intersections of arterial streets and the regime of movement on them. To lower transport noise, it is necessary to distribute freight and transit transport by city streets more rationally, use qualitative public transport, and limit the maximal speed regime on city streets. Further research on the road network will provide an opportunity to assess the noise level distribution of traffic flows in Lviv city. It will help to determine the problem places and propose methods of combating traffic noise.
\end{abstract}

Key words: traffic flow, noise level, speed of movement, freight transport, public transport, traffic flow composition, arterial street.

\section{INTRODUCTION}

Increased noise level is one of the most acute problems for an urban environment. Developed urban territory, especially in the areas of transport arterials, is in the zone of constant noise impact.

The primary source of noise pollution in large cities is road transport. A significant anthropogenic impact accompanies current processes of urbanization on the natural component of the city. Growth of population number, an increase of vehicles on city streets, reduction of green areas, and the density of built-up area directly affects the level of noise pollution of city territory. The problem of noise pollution is especially acute on the network of historically formed cities and cities with densely built-up areas.

Transport noise exceeds the natural noise level caused by the operation of engines, wheels, brakes, and aerodynamic properties of the vehicle. It is one of the forms of physical environmental pollution [1]. Reducing noise impact from road transport on the urban environment should be compulsorily reviewed in 
projects of construction or reconstruction of roads [2]. That is why it is necessary to develop measures in settlements concerning additional noise protection, namely additional landscaping, noise protection screens, etc.

The build-up of the environment and, consequently, road transport has a significant impact on the health of the population and the quality of life in cities. Noise pollution is one of the primary sources of the destruction of the environment, especially in central parts of cities [3].

Developing countries are experiencing rapid urbanization that directly and negatively affects their acoustic environment, mainly because of the increase of traffic intensity on urban arterials. Research of noise levels in cities points to the necessity of developing measures concerning its reduction by developing projects still under construction and expansion of residential areas [4]. Also, it is necessary to consider that the untimely introduction of control measures can make them ineffective. For reducing the noise, barrier protections and "floral" barriers are used. The barrier protection and vegetation combination effectively reduce the noise to 5-15 $\mathrm{dB}$ [5]. Thus, not everywhere is the possibility of installing such barriers, especially if it concerns the central part of the city with the historical area where buildings are located next to the street. Noise pollution from road transport has quite a negative impact on the environment of urbanized territories and people's health.

\section{RESEARCH STATEMENT}

The tendency of noise level increase in residential areas of large cities is observed today. The imperfection of legislative and regulatory frameworks and the absence of regulatory levers of control of permissive noise levels are the main reason for increasing noise pollution in cities. The level of transport noise on streets and roads depends on the intensity, speed and composition of traffic flow. Besides, it depends on the planning factors and elements of infrastructure. Each of these factors can change the level of transport noise. The increase of trucks, especially with diesel engines, in traffic flow causes the increase of transport noise.

The problem of noise pollution of city territory is topical nowadays because of the increase of the number of private transport and the growth of technical equipment of urban infrastructure. In current conditions of city development, the emphasis is made more frequently on reducing the noise load on the urban territory and the development of measures of its assessment. Because constant noise pollution of urban territories causes the increase of environmental hazards for population and the reduction of the quality of life in residential areas and along the city arterial streets.

The study aims to investigate noise levels generated by road transport on city arterial streets with the change of traffic flow indicators and the assessment of sources of noise pollution in city territory. It will provide an opportunity in the future, with the growth of motorization level, especially in conditions of dense urban built-up area, to justify the necessity of development of technical, planning, urban planning and regulatory measures for the protection of city territory in places where streets and roads are located. For achieving the aim of the study, such tasks are necessary to complete:

- to carry out field research of traffic flow intensity and composition on city streets;

- to carry out experimental measurement of noise generated by vehicles on city streets, considering the speed of movement of traffic flow;

- to determine the tendencies of the change of noise level depending on the traffic intensity and composition on city arterial streets;

- to develop practical recommendations about the reduction of the level of transport noise on city arterial streets. 


\section{INVESTIGATION OF IMPACT OF TRAFFIC FLOW INDICATORS ON NOISE LEVEL ON CITY ROAD NETWORK}

\subsection{Review of researches and publications about the assessment of noise level on arterial streets in cities}

The impact of noise generated by transport is essential in the current conditions of infrastructure development of the cities and urban environment.

Factors connected to the sound have an impact on the irritation from the noise: type of noise, level and frequency of noise, and human factors - physiological, psychological and social. In the study [6], the research of irritation from noise is carried out, which showed a strong correlation between the noise level, personal characteristics, and some living conditions.

It is noted in the research [7] that traffic flow composition and the distance from the source of noise to the nearest building are the most important factors that generate the noise on the streets and roads. Traffic flow and its composition, from the view of a significant share of trucks and the speed of movement, are determined as crucial factors that impact the generation of noise on the roads.

Noise from the traffic is the main problem of the urban population that lives close to arterial streets and roads. In cities with a densely built-up area, traffic flow affects the noise level, particularly trucks, different by its dynamic characteristics.

Noise, which road transport generates, is more disturbing near intersections where traffic flows, different by their composition, cross. Data about traffic flow was detailed near and in a zone of intersection using the speed of movement, measured in natural conditions for cars. Research results, given in paper [8], show that with the detailing of the intersection, there are differences in noise levels that can influence the measures, which can be used for noise reduction. However, the whole street should also be reviewed as the change of traffic organization at one intersection cannot solve the problem of noise pollution on the whole street.

Speed of traffic flow plays an essential role in transport noise generation. Many kinds of research indicate that the larger the speed, the higher the noise level, but the acceleration of vehicles is also an essential factor of noise generation, especially on low speeds and unsatisfactory roadway conditions [9]. It is necessary to accentuate the detailed characteristics of traffic flow composition as there is a significant share of trucks on arterial streets of the city that generate a significant level of transport noise.

One of the factors, which affect the level of transport noise, is traffic flow composition. Complex research [10] was carried out, where the assessment of traffic noise depending on vehicle types was conducted. It is noted that the noise generated by trucks is the largest.

The reduction of noise level from the traffic is one of the main urban environmental problems for today. Thus, architectures and urbanists make decisions about urban norms, which determine the form of streets and buildings, without considering this aspect [11]. That is why the conclusion was made that careful design of building facades and streets geometry can improve the noise climate for people that live and walk on the busy city streets, and it should be considered during the future design of city streets.

Pollution by road traffic has become the leading environmental problem that concerns the citizens of large cities. Authors [12] carried out the research of noise pollution based on the maps of noise. They noted that a significant noise level is observed near the central city arterials (Fig. 1). It is also mentioned that the noise level in off-peak hours is higher than in peak hours; it is connected with the increase of speed of movement of traffic flow in the off-peak period in the city.

The assessment of noise level from road transport in intersections is a more complex problem than the same analysis of streets and roads [13]. It is analyzed that the impact of intersection type and traffic flow characteristics is different for different schemes of traffic organization. Results show that with the same intensities of traffic flow at signalized intersections and roundabouts, the noise level is lower at roundabouts. The differences in intersections geometry, central island diameter and type of traffic flow maneuvers affect such a situation (Fig. 2). 


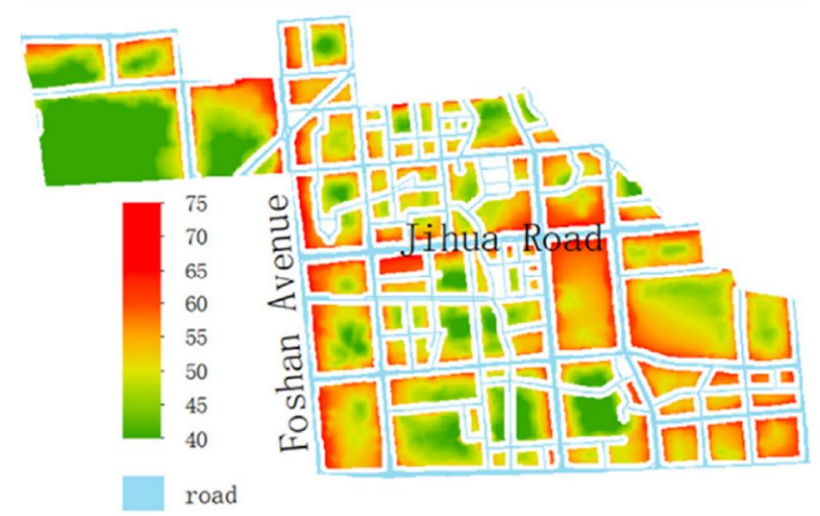

(a) 8:00-9:00

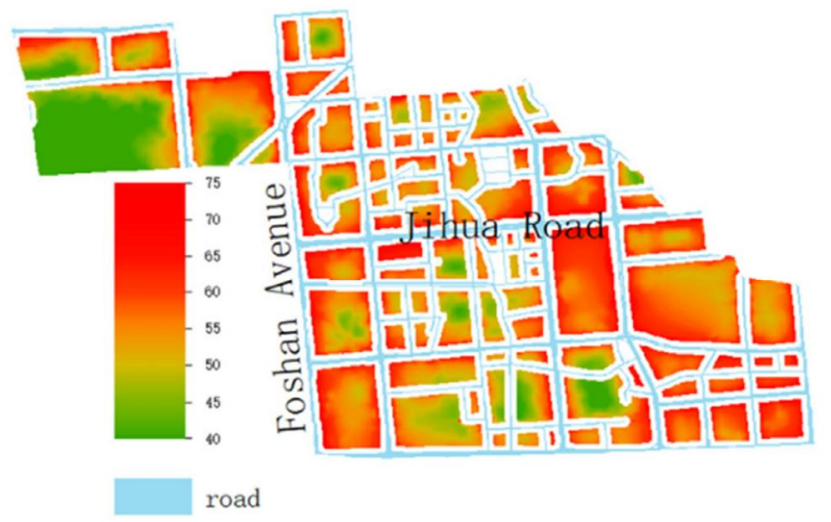

(b) 15:00-16:00

Fig. 1. The noise maps of class I area at the peak hour and off-peak hour (unit: $d B$ ).

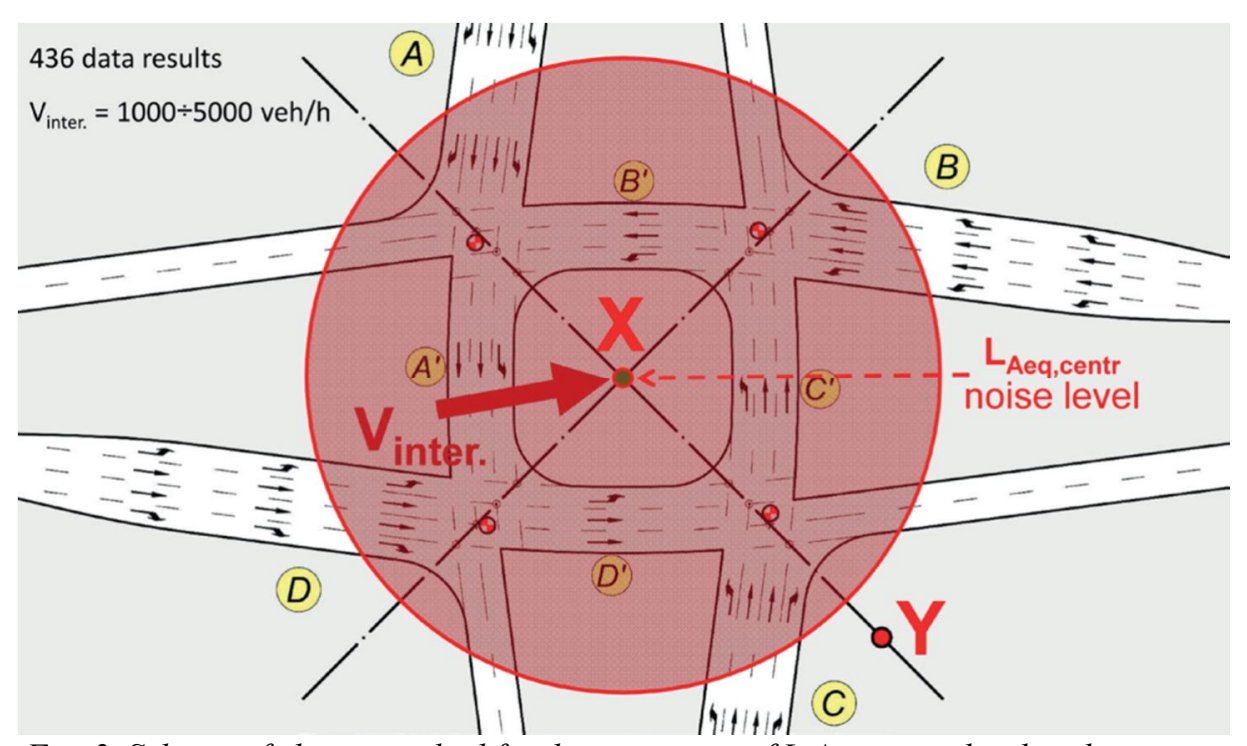

Fig. 2. Scheme of chosen method for determination of $L$ Aeq, noise level in the center: $X$-L Aeq, measurements in the center; Point of measurement $Y-L$ Aeq near intersection; $V$ inter. - general traffc intensity at the intersection.

During the research of the impact of noise on the human body, researchers pay special attention to the condition of hearing organs as auditory analyzer perceives sound vibrations, and its stimuli are adequate to the effects of noise on the human condition. Besides, perception of noise and its fluctuations is through the skin by vibration sensitivity receptors. A person receives much information with the help of an auditory analyzer, that is why the level of sound pressure determines the impact of sound signals on the auditory analyzer, and the intensity of sound is determined by the density of the flow of sound energy [14]. For the characteristics of values that determine sound perception, essential is not so many absolute values of sound intensity and sound pressure but their relation to threshold values.

The peculiarities of transport noise spreading, an insufficient number of noise protection facilities on different street sections, and their different planning characteristics determine the relevance of the topic and are the base for conducting the field research on the assessment of the noise on city arterial streets.

During the traffic organization in cities and their parts, it is necessary to control the noise level [15]. Nevertheless, it is quite difficult to control the noise level in every particular place, intersection or street. A relevant measure that reduces the noise level in cities is partial elimination of the noise source by restricting entering transport in the central part of the city. As research results [16] show, the restriction of 
entering will provide an opportunity to reduce the level of noise load on pedestrians and residents of the central part of the city and obtain the reduction of the amount of annual economic losses.

\subsection{Field research of noise level depending on the traffic flow speed on city streets}

Noise that occurs on the roadway of urban arterial is spreading not only on the roadside area but also in the depth of residential area. Parts of blocks and micro districts, located along the arterials of citywide significance, are in zones with the largest noise impact. The measurement of equivalent and maximal noise level should be carried out by integrating noise meters [17]. Noise meters of model SL-814 are used for the measurement of noise characteristics on the road network. They measure the noise of the range from 40 to $130 \mathrm{~dB}$. Streets where research of transport noise was carried out are given in Fig. 3.

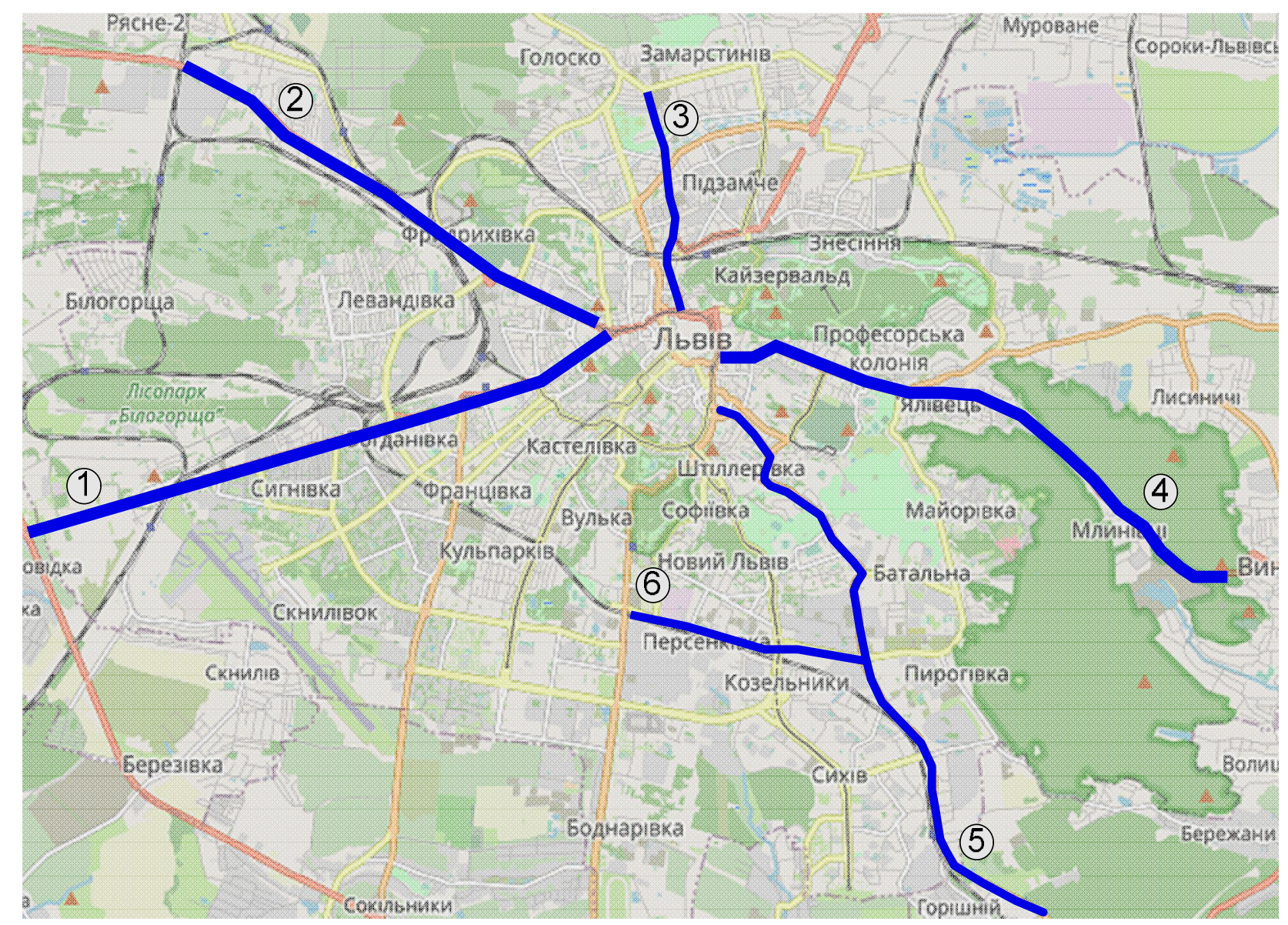

Fig. 3. Scheme of city streets location where the research of noise level was carried out: 1 -Horodotska Str., 2-Shevchenka Str., 3 -Zamarstynivska Str., 4-Lychakivska Str., 5 - Zelena Str., 6-Luhanska Str.

The measurements of noise characteristics of traffic flow were carried out on six streets. Arterial streets are characterized by one or two-lane roadways and different types of pavement - asphalt concrete and cobblestones.

The formed road network is the base for the arterial street system of Lviv city. It reflects the planning features of the city. By its scheme, the arterial street system is close to radial. Besides, the absence of the north section of the city bypass road causes the additional overloading of streets with transit transport in the northern part of the city.

Six streets were chosen for the assessment of noise level and its comparison with existing norms. Using the noise meter, we measured the noise generated by vehicles. Measurements of noise were carried out in peak, and off-peak periods, so it was also possible to record the speed of an individual vehicle. 
Noise levels from traffic flow were measured due to DSTU-N B V.1.1-33:2013 [18]. At the beginning of measurements, a map was created to outline measurements so that noise measurements were conducted along the whole street. The measurement of noise pollution was carried out by noise meter, which is designed to measure environmental monitoring of noise levels in settlements that are not far from roads.

Besides public transport, trucks have a significant impact on noise pollution. The majority of them passes the sections of the central part of the city. It is due to the service of many commercial objects located in the central part of the city and on its approaches, and with a significant residential area. Traffic flow composition on investigated streets is also researched to characterize the state of the noise environment. Obtained data of vehicle distribution by composition in traffic flow are given in the graphical form in Fig. 4.

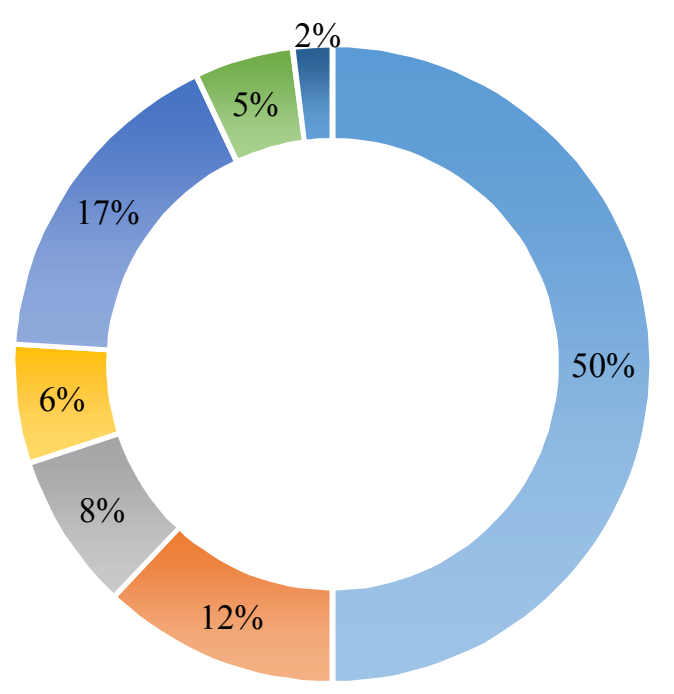

\author{
Cars \\ - Small passenger buses \\ - Large passenger buses, \\ trolleybuses \\ - Coupled buses and trams \\ - Trucks up to $6 \mathrm{t}$ \\ - trucks above $6 \mathrm{t}$ \\ - Road trains
}

Fig. 4. Percentage distribution of different vehicle types on investgated streets of Lviv city

During the traffic flow analysis on given streets of Lviv city, we established that the largest share has cars $-50 \%$. There are trams on Horodotska Str., Shevchenka Str., Zamarstynivska Str., and Lychakivska Str. The share of this vehicle type is $6 \%$. Trolleybuses are moving on Zelena Str. and Horodotska Str. Their share with large buses is $8 \%$ of the traffic flow. As chosen roads are arterial streets of the city, the share of medium-duty lorries (up to $6 \mathrm{t}$ ) is $17 \%$. A significant number of commercial shopping units and shopping and entertainment centres to which the transportation is carried out explains such a large share of this type of vehicle. The most negligible share is heavy vehicles.

Horodotska Str. is the longest arterial street in Lviv; its length is about $8,4 \mathrm{~km}$. There are low buildings (to 5 floors) on both sides of the street on the section of the street where noise level measurements were carried out. The tracks on which the tram runs are located in the middle of the roadway. Also, there is a large number of public transport units and suburban buses. Car lanes have a width of $3 \mathrm{~m}$, they are located on both sides of the tram tracks, near the edge of the roadway is a sidewalk $3 \mathrm{~m}$ wide, barriers and greenery are absent, the pavement is cobblestone.

Shevchenka Str. is one of the main arterial streets of Lviv city; its length is $8 \mathrm{~km}$. It is essential that the part of the street is covered with cobblestone, and part of the street has asphalt concrete pavement. A lot of freight transport moves along the street, which affects the condition of the pavement and noise pollution. Car lanes have a width of $3.5 \mathrm{~m}$. The quality of pavement is relatively low; there are many potholes. Greenery separates the sidewalk from the roadway. Residential buildings are low-rise.

Zamarstynivska Str. begins in the central part of the city and connects residents with the northerneastern part of the city. The length of the street is $4.5 \mathrm{~km}$. There is a one-lane roadway in both directions on the whole length of the street, its width $3.5 \mathrm{~m}$. Many trams are moving along the street. There is a densely built-up area on both sides of the street. 
Lychakivska Str. is an arterial street of controlled motion; its length is $4,8 \mathrm{~km}$. There is one lane in every direction on the street; the width of it is $3.5 \mathrm{~m}$. The pavement on the street is cobblestone. There is a significant slope of the roadway on the street. Apart from tram movement, there are many large and small passenger buses on the street. There is a densely built-up area along the whole length of the street.

Luhanska Str. is located in the Sykhivskyi district of Lviv city. There is a large number of the industrial territory of former motor depots, enterprises, warehouses, wholesalers and premises used by various commercial organizations along the street. There is a single-track railway and railway station Persenkivka nearby the street. That is why there is a vast amount of freight transport on the street. There is two-way movement on the street with one lane in every direction. The width of the lane is $3.5 \mathrm{~m}$.

In general, investigated streets are characterized by densely built-up areas, high intensity of different types of vehicles, public transport movement and stopping points.

The measurement of noise pollution of streets by traffic flows provided that during the measurement of noise characteristics, the measuring microphone was located on the sidewalk or roadside at a distance $2-5 \mathrm{~m}$ from the edge of the roadway and in places of the close location of buildings to the roadway - at a distance $1 \mathrm{~m}$ from the building façade and at the height of $1,5 \mathrm{~m}$ from the level of road pavement. Obtained data about the current noise level on streets is given in Fig. 5.

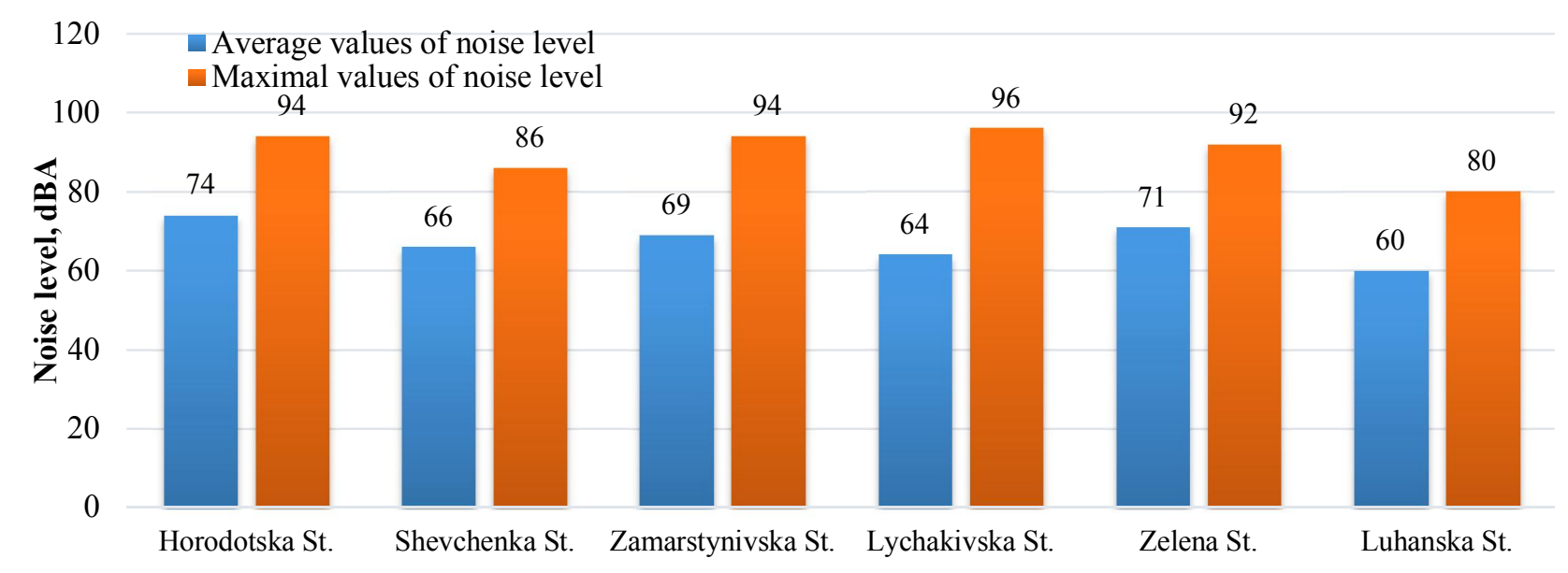

City arterial streets

Fig. 5. Results of noise level measurements on investigated streets of Lviv city

Due to Fig. 1, it is set that the most noise is generated on streets where trams move, and the road pavement is cobblestone. On Horodotska Str., Shevchenka Str., Lychakivska Str., and Zamarstynivska Str., the largest noise level is 94-96 dBA. On Zelena Str., due to the narrow roadway and a large share of public and transit transport in the direction of leaving the city, the traffic noise level is $92 \mathrm{dBA}$. Even on Luhanska Str., where the road pavement is asphalt concrete, the acceptable noise level along the streets exceeds the standard allowable values and is $80 \mathrm{dBA}$. Such high values of noise levels can be explained by the fact that the streets are in an industrial zone with a significant share of trucks, and there is a single-track railway and railway station nearby the street. High values of traffic noise level on the road network are caused by a large share of freight transport in traffic flow, a presence of tramcars that are the most significant source of noise among all types of vehicles. Besides, a significant factor that generates additional noise is that road pavement on streets is cobblestone. High noise levels negatively affect these streets' residents, as the distance to buildings is extremely small. If we consider Luhanska Str., which connects two arterial streets of the city, has a railway junction, and the residential area is almost absent along the street, and then it is possible to reduce noise pollution there for the expense of, for example, green planting. Thus, other streets begin in the central part of the city, and there is a densely built-up area along the streets, which limits the measures about reducing the level of noise pollution of city territory. 
The problem of the high volume-capacity ratio on arterial streets of Lviv city is related, in the first place, to the low capacity of streets, densely built-up area, and one lane per direction. As most streets chosen for the research are characterized by high traffic intensity, there are many signalized intersections and pedestrian crosswalks. Almost all sidewalks, pedestrian zones, and roadway expansions are used for parking of private transport. In general, there is a tendency for the increase of private transport in the city. So, we can conclude that investigated streets are characterized by a high volume-capacity ratio, which, in its turn, reflects in the noise pollution of the urban environment. Even with low speeds of movement on the road network, there is a high noise level along the streets. That is why the speed regime of traffic flow and the noise level along the streets was recorded on chosen streets. Obtained data about the current noise level depending on the speed of movement is given in Fig. 6.

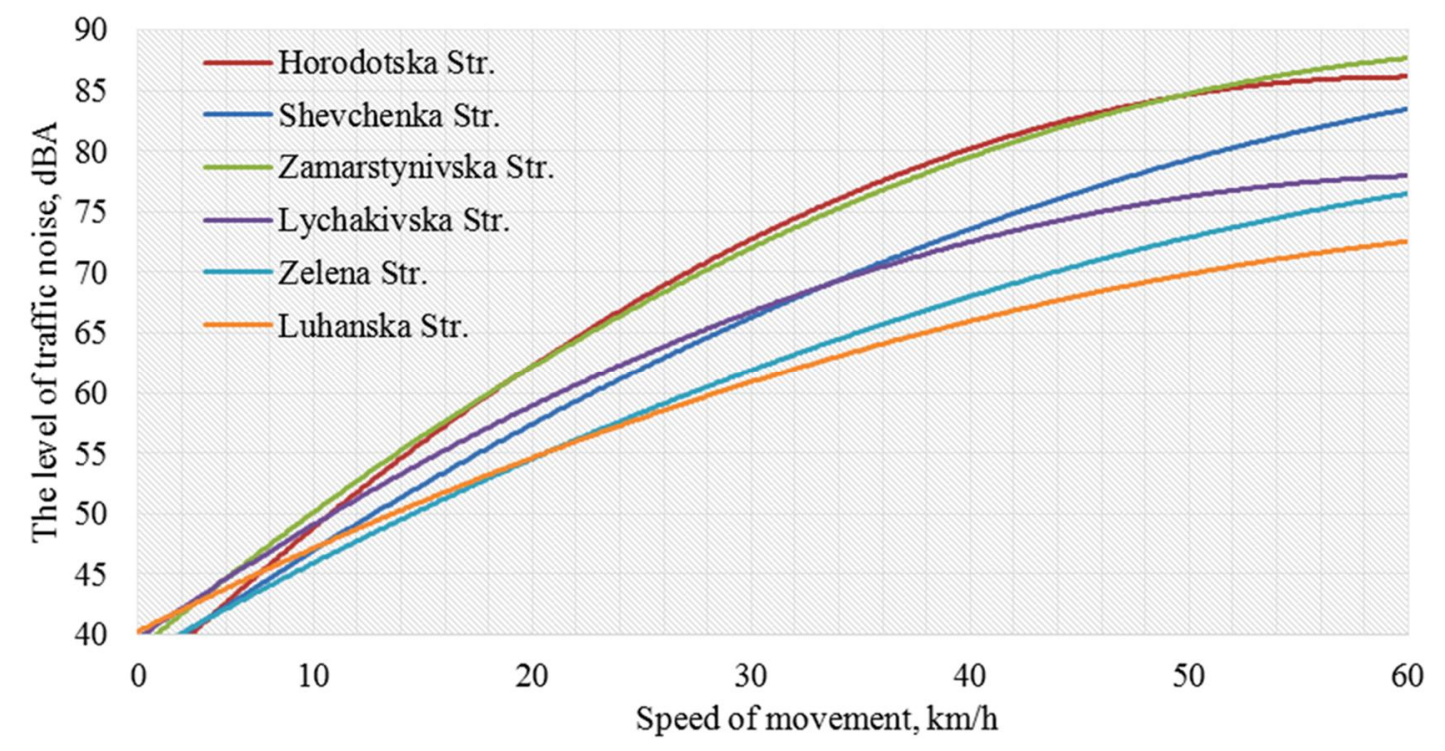

Fig. 6. Dependence of noise level from traffic flow speed on city streets

Research results of noise pollution depending on traffic flow speed indicate that traffic noise starts to exceed the acceptable norm at the average speed of movement $40 \mathrm{~km} / \mathrm{h}$ on the streets where road pavement is cobblestone. Also, a significant noise level is generated because trams are moving on Lychakiska Str., Shevchenka Str., and Zamarstynivska Str. They are characterized by unsatisfactory technical conditions and are pretty outdated and noisy. Due to Fig. 6, at the average speed of $40-50 \mathrm{~km} / \mathrm{h}$, the average noise level on Horodotska Str., Zamarstynivska Str., Shevchenka Str., and Lychakivska Str. is 70-73 dBA, which is more than the acceptable norm.

\subsection{Results of noise pollution research taking into account traffic flow composition}

Noise rationing in Ukraine is regulated by order №463 “About the statement of the State sanitary norms of admissible noise levels in rooms of inhabited and public houses and in the territory of a residential area" from 22.02.19, DBN V. 1.1-31:2013 "Protection of territories, buildings and structures from noise", and DSTU-N B V.1.1-33:2013 “Guidelines for calculation and design of protection against noise in residential areas" from 10.07.2013 № 306, valid from 2014-01-01. Due to these norms, it is assumed that on the territory of the residential area, during the exceeding of the acceptable noise level of $70 \mathrm{bB}$, it is necessary to mark with unique signs or use protective equipment in these zones.

With the growth of motorization level in cities, an increase of transport mobility of residents, increase of urban infrastructure, contacts between the technogenic and natural environment of the city expand. That is why, after researching noise level and traffic intensity on arterial Horodotska, Shevchenka, Lychakivska, Zelena, Luhanska, and Zamarstynivska streets, traffic flow composition is also taken into 
account. It is because a significant share of trucks, public transport and electric transport has noise impact on the roadside and residential area and urban space of the whole city. By research results, the dependence of noise level from the traffic intensity at the different share of freight and public transport is established in traffic flow on streets of Lviv city (Fig. 7).

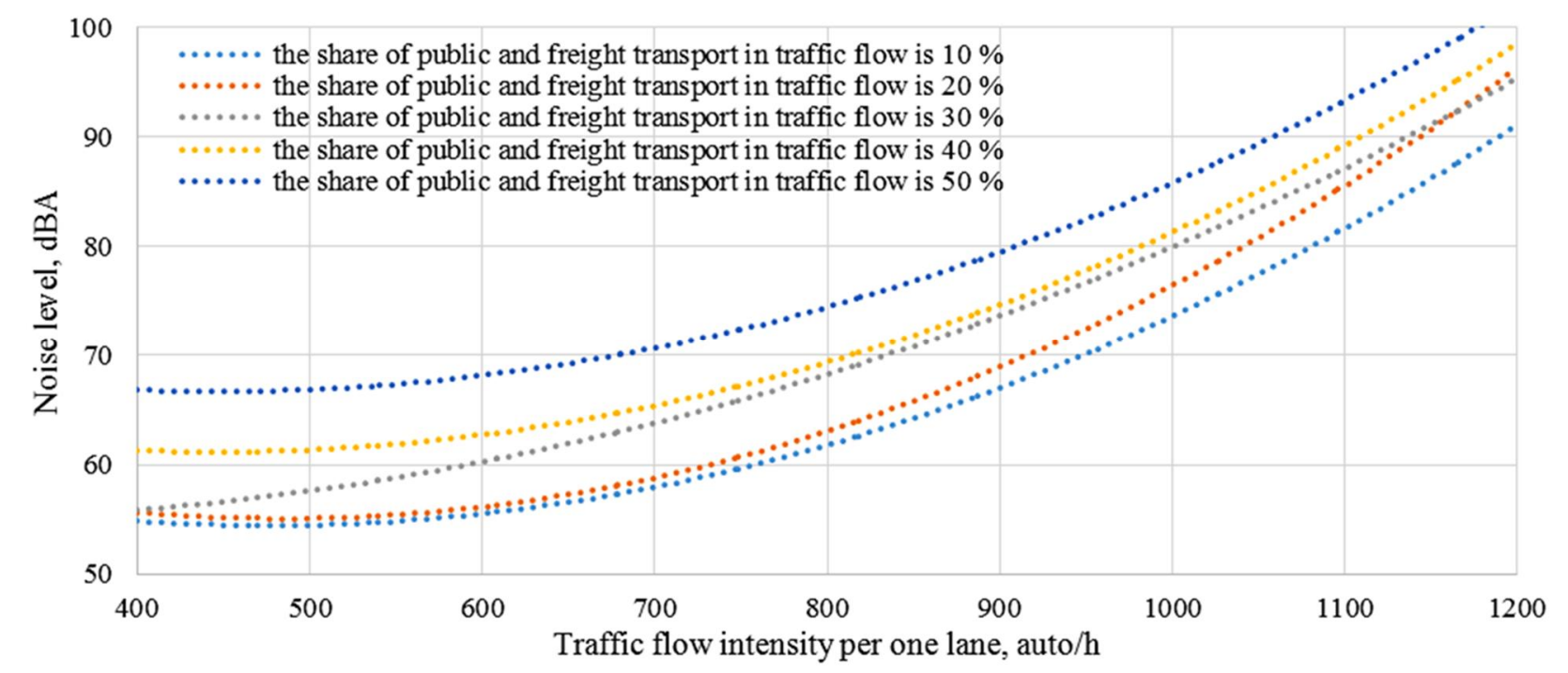

Fig. 7. Dependence of noise level on the traffic intensity at different share of freight and public transport in traffic flow

Comparing the noise level values, which is generated by road transport on streets, according to Fig. 7, we can see that the noise level is different on all streets with the increase of traffic intensity and the total share of freight and public transport per one lane. So, on streets with the highest volume-capacity ratio, even with a small share of freight and public transport, the noise level grows and is higher than acceptable (85 dBA). On Shevchenka Str., Horodotska Str., Lychakivska Str., and Zamarstynivska Str., additional noise is generated by cobblestone. There is a large share of transit transport on Zelena Str. and Luhanska Str. At the intensive movement of 800-900 auto/h and a small share of public transport of 10$20 \%$, the noise level does not exceed the acceptable norm in $70 \mathrm{dBa}$. With the increase of the share of freight and public transport over $20 \%$ and the growth of general traffic flow intensity, the noise level increases and will exceed the acceptable norm. On average, it will be $80-90 \mathrm{dBA}$. It can be explained by the fact that there are many public transport stops and signalized intersections on relatively small sections of streets where high noise level generates during the acceleration and deceleration on the approaches to these sections. Also, high values of traffic noise were observed on sections with the most saturated motion of public transport, as Horodotska Str., Lychakivska Str., Zelena Str., Shevchenka Str. are arterial streets where a significant share of public transport routes goes through. The city's public transport fleet has obsolete buses, which do not fully meet the modern standards of European countries, and high-class buses with diesel engines, which increases the noise load on the central part of the city. Apart from this, a significant impact on noise pollution has trucks, the majority of which run on streets sections servicing a large number of commercial facilities located in the central part of the city and on its approaches.

In general, freight and public transport cause significant noise pollution on the city territory. The typical indicator of noise level on streets was observed only at the small traffic intensity and the share of freight and public transport less than $30 \%$, so, considering that the distance to buildings is relatively small, the planting of greenery on both sides of the road in future can partly reduce its impact on residents. 
Results of noise level assessment can be considered in the development of a detailed construction plan and site landscaping near urban transport arterials. During the design or reconstruction of streets or roads which pass through the settlements, one of the main tasks is the protection of residential areas from noise impact. In case of exceeding the permissible noise level, it is necessary to arrange a buffer zone between the road and buildings; if it is impossible to do, it is necessary to install noise barriers to reduce traffic noise. It is advisable to use noise shields along ample avenues, highways and railways to reduce noise.

\section{CONCLUSIONS AND RESEARCH PERSPECTIVES}

Traffic flow is the primary source of noise pollution. The increase of freight and public transport share on city streets in more than $30 \%$ generates the average noise level above $70 \mathrm{dBA}$, which exceeds acceptable norms. It, in its turn, creates the necessity to develop and implement practical measures to reduce noise pollution on streets or their sections.

It is necessary to carry out the monitoring and the assessment of noise pollution to develop the measures for protection from noise during the design and construction of settlements and their parts, and also during the reconstruction and major repair of arterial streets and roads which, by its functional purpose, can generate excessive noise. It is established that for the provision of protection from noise or reduction of its level, it is necessary to consider existing intersections of arterial streets and traffic organization. For the reduction of traffic noise, it is necessary to distribute freight and public transport by city arterial streets more rationally, improve road pavement, use quality electric transport on urban public transport routes and maintain them in good condition. In cities, the main factor of noise reduction for cars is the regime of traffic flow movement that is why it is necessary to limit the maximum speed on city streets.

Reduction of noise level can also be obtained by the complex of such measures as improvement of transport and operational indicators of arterials, arrangement of citywide arterials of continuous and controlled motion with noise-shielding screens, the change of schemes of traffic organization and modernization of arterial road network of the city.

Results of field research of noise level have essential applied value and can be used to develop architectural and planning activities to reduce noise pollution in cities with densely built-up areas.

\section{References}

1. Anees, M., Qasim, M., \& Bashir, A. (2017). Physiological and physical impact of noise pollution on environment. Earth Science Pakistan, Volume 1(1), 08-11. doi: 10.26480/esp.01.2017.08.10 (in English)

2. Vnukova N. V.(2011) Otsinka akustychnoho zabrudnennia prydorozhnoi terytorii avtomobilnoi dorohy [Assessment of acoustic pollution of the roadside area of the highway] Skhidno-Yevropeiskyi zhurnal peredovykh tekhnolohii [Eastern-European Journal of Enterprise Technologies], Volume 4(6), 42-47. doi:10.15587/17294061.2011 .1423 (in Ukrainian)

3. Roudsari, H.K., \& Chandrashekara, B. (2017). Assessment of the noise quality level as an urban design parameter and impact of pedestrianisation in tehran's city center. Journal of international academic research for multidisciplinary Impact Factor, Volume 5, Issue 3. 103-114. (in English)

4. Nascimento, E.O., Oliveira, F.D., Oliveira, L., \& Zannin, P.H. (2020). Noise prediction based on acoustic maps and vehicle fleet composition. Applied Acoustics, Volume 174. 107-118. doi:10.1016/j.apacoust.2020.107803. (in English)

5. Lacasta A. M., Peñaranda A. and Cantalapiedra I. R. (2018) Green streets for noise reduction. Nature Based Strategies for Urban and Building Sustainability. 181-190. doi: 10.1016/B978-0-12-812150-4.00017-3. (in English)

6. Jakovljevic, B., Paunovic, K., Belojevic, G., (2009). Road-traffic noise and factors influencing noise annoyance in an urban population. Environment International, 35(3): 552-556. doi: 10.1016/j.envint.2008.10.001. (in English) 
7. Alimohammadi, I., Nassiri, P., Behzad, M., \& Hosseini, M. (2005). Reliability analysis of traffic noise estimates in highways of Tehran by monte carlo simulation method. Iranian Journal of Environmental Health Science \& Engineering, 2, 229-236. (in English)

8. Covaciu, D., Florea, D., \& Tímár, J. (2015). Estimation of the noise level produced by road traffic in roundabouts. Applied Acoustics, 98, 43-51. doi:10.1016/j.apacoust.2015.04.017. (in English)

9. Alam P., Ahmad K., Afsar S. and Akhtar N., "Validation of the Road Traffic Noise Prediction Model RLS90 in an Urban Area", 2020 3rd International Conference on Emerging Technologies in Computer Engineering: Machine Learning and Internet of Things (ICETCE), 2020, pp. 1-4, doi: 10.1109/ICETCE48199.2020.9091759. (in English)

10. Figlus T., Gnap J., Skrúcaný T., \& Szafraniec P. (2017). Analysis of the influence of different means of transport on the level of traffic noise. Scientific Journal of Silesian University of Technology. Series Transport, 97, 27-38. doi: 10.20858/sjsutst.2017.97.3. (in English)

11. Sánchez, G., Renterghem, T.V., Thomas, P., \& Botteldooren, D. (2016). The effect of street canyon design on traffic noise exposure along roads. Building and Environment, 97, 96-110. doi: 10.1016/j.buildenv.2015.11.033 (in English)

12. Yang, Weijun \& He, Jinying \& He, Canming \& Cai, Ming. (2020). Evaluation of urban traffic noise pollution based on noise maps. Transportation Research Part D: Transport and Environment. 87. doi: 10.1016/j.trd.2020.102516. (in English)

13. Li F., Liao S., \& Cai M. (2016). A new probability statistical model for traffic noise prediction on free flow roads and control flow roads. Transportation Research Part D-transport and Environment. 49, 313-322. doi: 10.24425/bpasts.2020.134190. (in English)

14. Kihlman T. Kropp W., Lang W. (2014) Quieter Cities of the Future. Lessening the Severe Health Effects of Traffic Noise in Cities by Emission Reductions. International Council of Academies of Engineering and Technological Sciences,. 1-28 p. Retrieved from https://www.newcaets.org/wp-content/uploads/2021/04/ QuieterCities-ofthe-Future-May-2014-2.pdf. (in English)

15. Khan, J., Ketzel, M., Kakosimos, K., Sørensen, M., \& Jensen, S. S. (2018). Road traffic air and noise pollution exposure assessment - A review of tools and techniques. Science of The Total Environment, Volume 634, 661-676. doi: 10.1016/j.scitotenv.2018.03.374 (in English)

16. Kachmar R. (2013) Otsiniuvannia ekolohichnykh ta ekonomichnykh vtrat vid shumu transportnykh potokiv mista Lvova [Estimation of ecological and economic losses from noise of transport flows of the city of Lviv], Avtoshliakhovyk Ukrainy [Road Transporter and Road Constructor of Ukraine], 1(231), 10-13. (in Ukrainian)

17. Zakhyst terytorii budynkiv $i$ sporud vid shumu [Protection of territories, buildings and structures from noise]. (2013). DBN ISO V.1.1-31:2013 from 01th June 2014. Kyiv: Ministry of Regional Development (in Ukrainian)

18. Nastanova z rozrakhunku ta proektuvannia zakhystu vid shumu selbyshchnykh terytorii [Guidelines for the calculation and design of noise protection of residential areas]. (2014). DSTU ISO N B V.1.1-33: 2013 from 01th January 2014. Kyiv: Ministry of Regional Development (in Ukrainian)

Received 15.09.2021; Accepted in revised form 19.10.2021.

\section{ОЦІНКА РІВНЯ ШУМУ НА МАГІСТРАЛЬНИХ ВУЛИЦЯХ ЗАЛЕЖНО ВІД ПОКАЗНИКІВ ТРАНСПОРТНОГО ПОТОКУ}

Анотація. Інтенсивність транспортних потоків зростає кожного року та значно посилюе свій вплив на екологічну ситуацію та природнє середовище міської території. В містах України зростання шумового забруднення є дуже актуальною проблемою, тому щь це сприяє великому навантаженню на навколишне середовище, у зв'язку із зростанням кількості автомобільного транспорту. Інтенсивність транспортних потоків і підвищення щцільної забудови призводить до зростання рівня шуму. Аналітичні методи розрахунку визначення рівня транспортного шуму мають низку недоліків. Для оцінки рівня шуму на 
магістральних вулииях м. Львова проведено дослідження із урахуванням показників транспортних потоків. Одним із ключових чинників, які впливають на шумове забруднення міського простору, є склад транспортного потоку, який рухається вулииями міста. Проведені дослідження вказують на те, щзо швидкість транспортного потоку створює значне шумове забруднення, особливо на вулииях, де дорожнім покриттям є бруківка. Вантажний та пасажирський транспорт, який рухається магістральними вулииями міста викликає підвищення рівня шуму та збільшуе його вплив на міську територію. На ділянках магістральних вулищь у пікові періоди доби за високого рівня завантаження дороги рухом та загальної частки вантажного і громадського транспорту більше ніж 30 \% у потоиі шум перевищує допустимі норми та шкідливо впливає на навколишнє середовище. Тому оиінку шумового забруднення та розроблення заходів захисту від шуму необхідно виконувати під час планування $i$ забудови окремих міських територій чи житлової забудови. Встановлено, щзо для зниження рівня шуму на вулицях потрібно враховувати наявні перехрестя магістральних вулиць та режим руху на них. Для зниження транспортного шуму потрібно раціональніше розподіляти вантажний та транзитний транспорт міськими вулииями, використовувати якісний громадський транспорт та обмежувати максимальний швидкісний режим на вулииях міста. Подальші дослідження на вулично-дорожній мережі дадуть змогу детальніше оцінити розподіл рівня шуму транспортних потоків. Це допоможе виявити проблемні місия та запропонувати методи боротьби з транспортним шумом.

Ключові слова: транспортний потік, рівень шуму, швидкість руху, вантажний транспорт, громадський транспорт, склад транспортного потоку, магістральна вулиия. 